\title{
Impacts of COVID-19 pandemic on national security issues: Indonesia as a case study
}

\author{
Md. Mahmudul Alam ${ }^{1}$ (D) Agung Masyad Fawzi ${ }^{1} \cdot$ Md. Monirul Islam² \\ Jamaliah Said ${ }^{3}$
}

Accepted: 27 August 2021 / Published online: 6 October 2021

(c) The Author(s), under exclusive licence to Springer Nature Limited 2021

\begin{abstract}
The national security issues in particular non-traditional security issues such as law enforcement, health, food, supply chain management, industry etc. are severely impacted by the COVID-19 outbreak in all countries of the world. As such, the developing country like Indonesia has largely been suffering from this epidemic. In this context, this paper attempts to analyse some national security issues that are affecting Indonesia, which is currently struggling with the COVID-19 pandemic. Proposed here are policy measures to combat both present and future challenges. The study uses secondary data collected from different sources concerning COVID19 pandemic and security issues of Indonesia. The study analyses the data based on descriptive statistics, highlighting the impact of the COVID-19 pandemic on Indonesian law enforcement issues, and security of health, food, supply chain management, industrial and other economic sectors. The study argues that if the vulnerability continues in these security-related issues due to pandemic, the country will face a harsh reality to manage the state-affairs. Therefore, the policy options are mainly concerned with the COVID-19 issue. Indonesia's government should identify what measures to take by conducting rapid diagnostics and polymerase chain reaction tests in the laboratory, respectively. Moreover, the government and relevant stakeholders need to develop strategies that break the stranglehold of COVID-19 transmission in order to resolve Indonesian national security concern.
\end{abstract}

Keywords COVID-19 · Law enforcement · Health security · Economic security · Social security $\cdot$ Food security $\cdot$ Supply chain management

Md. Mahmudul Alam rony000@gmail.com 


\section{Introduction}

The COVID-19 pandemic has had a disastrous impact on the world economy. Much of humanity's everyday life is now in colossal threat due to the pandemic. Although this virus is a recent one; it is not the first of its kind. In 1960, the first case of a coronavirus was identified as a cold. A Canadian study in 2001 revealed that about 500 people were classified as infected by a flu-like organism. Of these, there were 17-18 cases reported as polymerase chain reaction infected with a coronavirus. Until 2002 a coronavirus was regarded as a common non-fatal epidemic by physicians. Numerous published papers demonstrate the spread of a coronavirus in many countries viz. USA, China (specifically Hong Kong), Singapore, Thailand, Vietnam, and Taiwan since 2003. Many cases of extreme acute respiratory syndrome induced by a coronavirus were documented in 2003. To observe the unusual death toll rate, WHO and disease control and preventive centres declared a global emergency in 2004. Later on, the Chinese authorities notified WHO about some cases of pneumonia of uncertain aetiology on December 31, 2019. Then the Chinese Research Authority reported 44 cases of pneumonia as of 3rd January 2020, highlighting the origin of this new virus from the marine food industry in the City of Wuhan on January 7 , 2020. This virus was given the name 2019-nCOV (Kumar et al. 2020; Changotra et al. 2020; Bherwani et al. 2020; Gautam 2020).

In developing countries, the pandemic has severely been affecting not only the health sector but also the overall socio-economic spectrum. It is expected that wage deficits in these economies will reach $\$ 220$ billion. Approximately 55\% of the world's population will be devoid of access to social services and consequently, the economies will go through huge rises in unemployment, lack of civil rights, restricted access to food security, etc. Hospitals and clinics are likely to experience potentially devastating situations due to the overcrowding caused by patients and the lack of sanitising materials like soap and water for at least $75 \%$ of people in the least developed or developing countries. These countries include Madagascar, Iran, Vietnam, Panama, Ukraine, Serbia, Paraguay, Nigeria, Kyrgyzstan, China, Eritrea, El Salvador, Djibouti, Herzegovina, and Bosnia. Other socioeconomic problems, such as inadequate urban planning and overpopulation, insufficient waste disposal infrastructure and even road congestion will impede people's access to healthcare facilities and contribute to the medical caseload (Wingard 2020).

All affected countries are hardly prepared to face both the challenges and losses that are evident in healthcare and other sectors of the economy. Indonesia as a developing country has not responded well to the crisis as the government has to protect many non-traditional national security issues such as public policy, health, social cohesion, daily goods/services consumption, national supply chain management, etc., which are now badly impacted by COVID-19 (Nainggolan 2020).

According to the Center for Strategic and International Studies (CSIS 2021), related to the COVID-19 cases in Southeast Asia, Indonesia ranks the highest with 1 million cases, and the death rate is almost 30,000 people. In the Southeast Asia region, Indonesia has become the country with the most COVID-19 cases to date. This is due to the Indonesian government's actions to further relax travel regulations 
and restrictions on gathering in various provinces. This action was taken by the Indonesian government in an effort to reopen and increase economic activity during the global pandemic period. Meanwhile, it is known that the actual number of COVID-19 cases in Indonesia has exceeded the official number announced by the government in January 2021. The confirmed COVID-19 cases keep increasing in the country related to the availability and distribution of vaccines throughout Indonesia, given that Indonesia is an archipelagic country. Then, after Indonesia became a country that also approved the use of the Sinovac vaccine, apart from China, Indonesia started a vaccination program in mid-January 2021. But unfortunately, COVID19 cases in Indonesia continued to soar because first of all there was a lack of availability of testing equipment and the second was the system, in which the small-scale zone locking that is not properly supported by local authorities (Ketchell 2021).

The Indonesian government attempted to implement some special set of rules: one that has isolated areas affected by the pandemic and enabled the deployment of military forces to deal with disaster-laden emergencies in those regions where transmission of the virus is difficult to control. Despite this, there is no alternative given the nature of national security threats (Power 2020). However, to deal the crisis properly, policymakers need to take immediate actions in both the short- and long-term. In fact, the government should have anticipated and dealt with the various existing and upcoming dangers, including the potential threat to national security. Urgent and useful suggestions and inputs were required to predict the prolonged effect of the pandemic including economic resilience, food security, and technology development. Moreover, national security issues are also needed to analyse from non-traditional national security perspective for avoiding mismanagement in disaster of overall state-affairs and follow a holistic approach for the survival of Indonesia.

Therefore, to understand COVID-19-induced problems in the national security issues, this study aims to analyse the impacts of COVID-19 on Indonesian national security issues from non-traditional national security perspectives like law enforcement, health, social cohesion, food supplies, and supply chain management for industry. Here the descriptive analysis technique is employed.

The study chooses Indonesia because it is now recognised as one of the most vulnerable countries in terms of the rapid and fatal spread of the pandemic. Starting on 2nd March, 2020, the total COVID-19 infections have exceeded 50,000 (Worldometer 2020) and numbered exactly 52,812 as of June 27, 2020. Of these, 21,909 people recovered fully along with the total death case count of 2720 . According to the recent data on July 13th, 2021, Indonesia has even reached more than 2.5 million confirmed cases of COVID-19 within the country (Worldometer 2021). Therefore, studying on Indonesia will also be beneficial for other similar countries of the world.

Moreover, this study also contributes by providing significant insights for policymakers and other parties involved in maintaining national security and thus find better solutions to deal the COVID-19 pandemic in Indonesia. The study will benefit both the central and local governments of Indonesia to be well informed of the various potential impacts of COVID-19 on national security issues. Also, the world's major economies can consider their strategies for supporting businesses based on the outcomes obtained from this analysis of Indonesia. 


\section{National security related to the COVID-19 pandemic}

\section{Concept of national security}

According to Grizold (1994), the security issue is closely associated with various natural and societal features, processes and activities. National security as a collective or broader phenomenon is defined as: "an intricate interaction between political, economic, military, ideological, legal, social and other internal and external social factors through which individual states attempt to ensure acceptable provisions to maintain their sovereignty, territorial integrity, the physical survival of its population, political independence and possibilities for a balanced and rapid social development on an equal footing". National security is not only influenced by politics but also by the economy, society and culture, including human rights, welfare of the people and environmental safety.

To safeguard the interests of the people and their territory is a fundamental task of the government or state. It basically means protecting people from external attack. Internal protection is just as important and to tackle those insiders or insurgents who wish to do damage to the wider community from within. Recently, these internal challenges and threats are increasingly widespread (Wahyono 2017). National security is of two types: traditional and non-traditional security. Traditional security or security threats are described through a country's survival prism and anticipated predominantly in the case of inter-state military clash. In recent years, non-traditional security issue is considered to be connected with issues involving environmental degradation and climate change, infectious disease, terrorism, transnational crime, and illegal migration (Hameiri and Jones 2013). These issues not only threaten the existence of the state directly, but they challenge the capacity of the state to safeguard its people (Grizold 1994).

The COVID-19 pandemic within a country has hugely disrupted the total security especially non-traditional security apparatus of many countries. The colossal threat to the healthcare sector of different countries has contributed to radical changes in government policies both domestically and internationally. Policies have had to change in order to deal with the pandemic. More specifically, COVID-19 has directly affected countries' economic security in terms of leading to unfavourable changes in inflation and interest rate, GDP growth, exchange rate and unemployment rate. New government policies now have to consider social security/welfare issues so that the bulk of people can be looked after now that businesses have closed down. For instance, the principle of working from home (WFH) is not something that every person can do. Moreover, COVID-19 is impacting on the supply chain management now that the import and export of goods and services, especially in the manufacturing industries, is greatly curtailed and resulting in significant losses in industry, profits and employment. This situation gravely threatens the major developing economies like Indonesia that are largely trade dependent. Overall, the non-traditional security aspects of Indonesia, especially law enforcement, economy, health, supply chain management, food, social relations have been suffering from the COVID-19 pandemic. 


\section{Law enforcement}

Law and order in Indonesia has been greatly affected by the spread of COVID19. The law enforcers are under continuous pressure by the authority concerned concerning their responsibility. In most cases, these people are paying twofold duty pressure to deal with the pandemic situation. The infection rate among law enforcers has been rising day by day. Some of them are detached from the familial life due to their posting that is far away from their native area. More importantly, the lockdown has compelled them to experience this detachment from their families. Being long-time separated from families, many law enforcers especially the members of the police force are witnessing mental health problems such as anxiety. This has drawn serious attention to the policymakers concerning the viable application of law enforcement in tackling the COVID-19 pandemic in Indonesia. Without the sound mental health of law enforcers, social distancing measures, lockdown, shutdown, etc. cannot be successful amid the explosive infection rate of the COVID-19 epidemic though the policy initiative of the government relating to infection control is notable.

The President of Indonesia, Joko Widodo (Jokowi), signed Government Regulation No. 21 of 2020 concerning 'large-scale social restriction'. Here the President allowed local governments to implement large-scale social restrictions in order to prevent the spread of the coronavirus. There are seven articles listed on the new government regulation. Large-scale social restrictions will be imposed on certain activities carried out by residents in an area suspected of being infected with COVID-19. The policy is being enacted by local governments with the approval of the Indonesian Ministry of Health, including the closure of public places, insulating public transport, and restricting any travel to and from restricted areas. Moreover, the restriction must fulfil two objectives: reduce the number of positive cases and reduce the number of deaths in all affected regions (Arnani, 2020). The government has also announced that a civil emergency policy will be enacted to minimise and tackle the spread of COVID-19. The "civil emergency policy' is part of a Government Regulation in lieu of Law No. 23 of 1959 concerning the State of Danger. A state of emergency is declared if security or law and order throughout the territory or in parts of the Republic of Indonesia are threatened by rebellions, rioters, or due to natural disasters. Normally, such a type of crisis cannot be overcome by using the security mechanism in an ordinary manner. Furthermore, the state itself will implement an abnormal state emergency law to cope with extraordinary events in such a way that immediately the state situation can return to normal as before. Based on the stated emergency policy, the COVID-19 pandemic has ensured the regulation is in fact a special authority (prerogative authority) of the President of Indonesia to implement an emergency policy (Novianto 2020). 


\section{Health security}

Health security functions to maintain a minimum level of protection from diseases and ensure the safety of all citizens. However, there are debates among health experts and stakeholders about the concept of health security and what it means for public health. Both preventive and remedial measures are required to mitigate the risk of public health dangers that pose colossal threats to individuals domestically or globally (Aldis 2008). International Health Regulations (IHR) underscores the need for public health intervention to deter, track, and respond to incidents so that the outbreak of infectious diseases can be documented and responded to. The COVID-19 epidemic has exposed the lack of capacity and performance to ensure public health security. Indeed, many countries are struggling in their ability to deter, identify and respond to the epidemic. Most of the surveys carried out in different countries depict a lack of adequate resources, a clear consistent strategy, differences between national or region/state authorities to respond to pandemic outbreaks, so the responses to COVID-19 are not appropriate or simply make the problem worse.

Regarding the influence of the coronavirus on health security in Indonesia, President Jokowi has also stated that COVID-19 is such a dangerous disease that it will cause public health emergencies. The government determines the status of Public Health Emergency in all regions of the country. To regulate the status of public health emergencies, the President has signed and ratified the Government Regulations and Presidential Decrees concerned with coronavirus-related issues. Law No. 6 of 2018 concerning Health Quarantine, as stipulated in Article 1 paragraph 2 , states that public health emergencies are an extraordinary issue marked by the spread of infectious diseases or events which are caused by nuclear radiation, biological pollution, chemical, contamination, bioterrorism, and food problems. All these phenomena pose health hazards and will potentially spread throughout the country (Sadikin 2020). In this situation, the government can identify and revoke the entrance of people from affected countries to Indonesian territory as revealed in Article 10, paragraph 2. The intended entrance includes the entry and exit points of transportation, people, or goods in the form of a port, airport, or national land border-crossing post. Indonesia has temporarily prohibited the entry and transit by foreign nationals to curb the transmission of COVID-19 and prohibit foreign ships from docking or berthing at Lewoleba Port (Nusa Tenggara Timur Province), Ferry International Port in Batam City (Riau Province), Gilimanuk Port (Bali Province), Ketapang Banyuwangi Port (East Java Province), and Tanjung Priok Port (Jakarta Province) (Agustino 2020).

The Director General of Air Transportation under the Ministry of Transportation, Novie Riyanto, stated that air transportation now prohibited any travel within the country and across the borders using either scheduled or charter air transport. However, this prohibition did not apply to leaders or senior officials, foreign guests and representatives of countries or international organisations, or to the repatriation of Indonesian citizens and foreign nationals affected by the coronavirus. Exceptions also apply to cargo transportation and other operations with the permission of the government. Determining who or what can enter is regulated by the government. In 


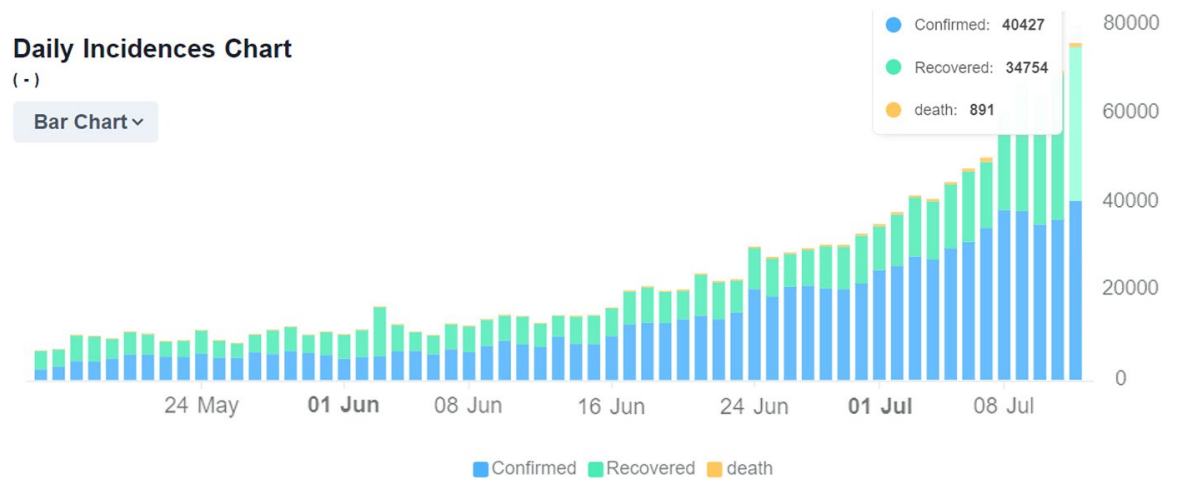

Fig. 1 Daily records of COVID-19 case development in Indonesia (July, 2021). Source https://www. coronatracker.com/country/indonesia/

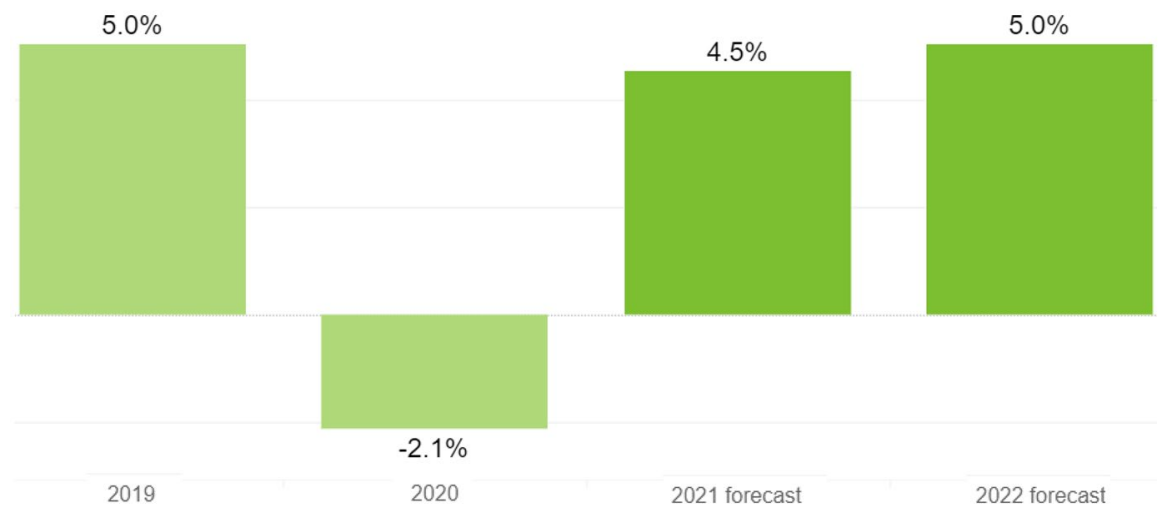

Fig. 2 Impact of coronavirus on GDP growth in Indonesia. Source Asian Development Bank (2021)

addition, the central government can identify the entry point to be taken under the quarantine framework. This implementation process is regulated through a Government Regulation, based on Article 14, paragraphs 1 and 2 (Sadikin 2020). Following Figs. 1, 2 and 3 depict the health security-related issues such as coronavirus case identification, institutional quarantine and home quarantine in Indonesia.

Currently Indonesia has reached 2,567,630 million total cases of COVID-19 within the country, on 13th of July 2021, along with 2,119,478 million people who have recovered and total of 67,355 of the death cases. Also, the daily confirmed case of COVID-19 keeps increasing in the country, especially from May to July 2021, and recently has touched 40,427 positive cases per day (Fig. 1). 


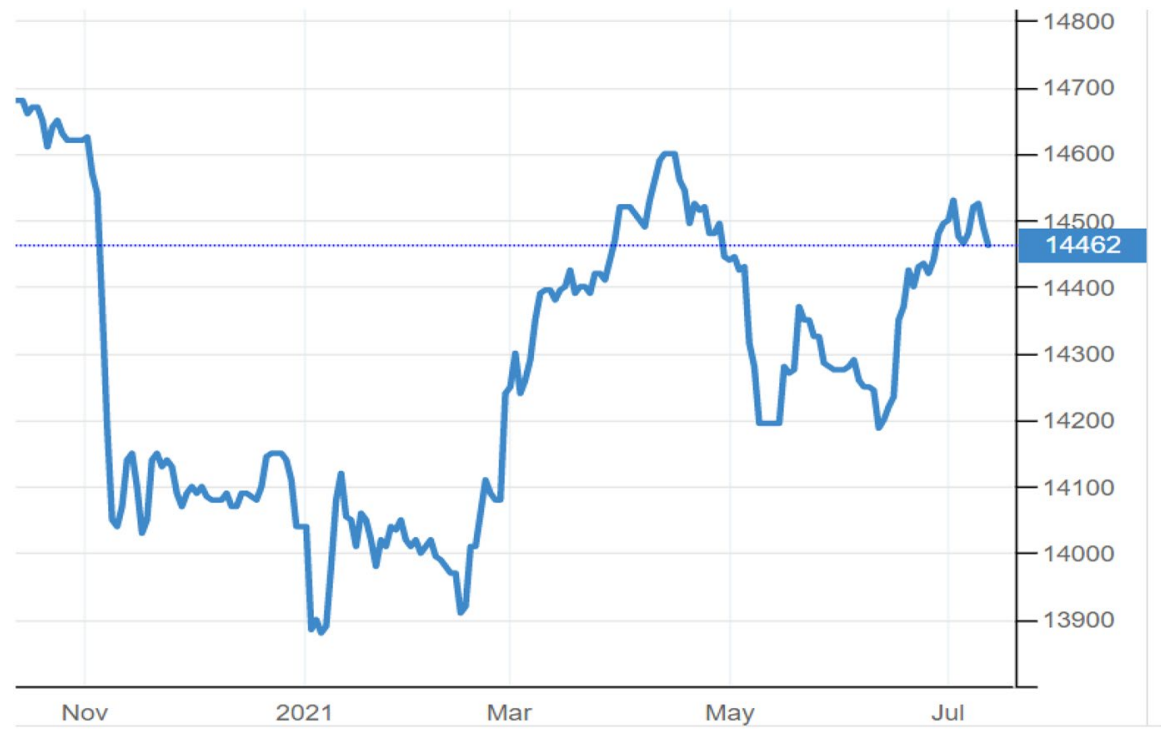

Fig. 3 Indonesian rupiah (IDR) against the US dollar (USD) to July 14th, 2021. Source https://tradingeco nomics.com/indonesia/currency

\section{Economic security}

Generally, economic security encompasses basic social security, including access to basic needs infrastructure concerning education, health, information, dwelling, and social safety, as well as work/job-related security (ILO 2012). From the micro perspective, economic security means having a fair chance of an individual to pursue preferred employment and cultivate their aptitudes. The macro-level economic security is associated with the viable inflation rate, employment, fiscal initiative and its implementation, business and trade and overall growth scenario of a state. The COVID-19 pandemic has a devastating impact on both the micro and macro-level economic security of Indonesia.

The sharp drop in both the local and foreign tourists was unavoidable. Workers have lost their jobs in the tourism sector and will potentially need to find new ways of making money. This happened due to the collapse in business for Micro, Small and Medium-sized Enterprises (MSMEs). Globally, MSMEs provide the most employment, and particularly for Indonesia these are the basic economic pillar of the country. New and effective ways need to be found for MSMEs to cope with the COVID-19 pandemic and in particular their access to working capital and finance, adjust their marketing practices to boost demand for their products, otherwise social protection, social dialogue, and social cohesion will be at great risk (ILO, 2020). The Indonesia Liputan6 Website, the World Travel and Tourism Council predicted that 75 million workers in the travel and tourism sector could lose their jobs (Hidayati 2020). In Indonesia, the spread of the coronavirus has greatly damaged the tourism industry, evident in the decline in the 
number of tourists visiting since January 2020. The tourism sector suffered a loss of US\$1.5 billion, the bulk of this loss being the number of tourists from China. In effect the COVID-19 pandemic has led to the closure of 1226 hotels and led to 150,000 people losing their jobs (Pristiwasa 2020).

According to the Katadata website, the significant impact of COVID-19 has forced manufacturing companies to reduce their production systems drastically. Employees are asked to take turns off which leads to their incomes falling by half. Situations where staffs are laid off, mean that companies must calculate severance pay. Workers end up "forced" to return home or having to find another job. Imports of raw materials have declined because there is nothing to process and the final result of the manufacturing process is much less exports because foreign demand has collapsed. The effect of COVID-19 in Indonesia is one where the gross domestic product (GDP) is forecasted and explained in Fig. 2.

Based on Fig. 2, Indonesia's GDP growth was forecasted to increase from $-2.1 \%$ last year (2020) to around 4.5\% this year (2021). Moreover, the spread of the coronavirus resulted in high fluctuations of the exchange rate for the Rupiah against the US dollar that performed from IDR 14,605 per USD (November 2nd, 2020) to IDR 14,174 per USD (January 6th, 2021) and then it drops to IDR 14,462 per USD by July 14th, 2021 (Fig. 3).

According to one recent study (Nicola et al. 2020), the current major issue is the global economic recession where most restrictions have led to higher unemployment rates and greatly reduced manufacturing activities. Additionally, it has negatively affected global stock markets where stock market on S\&P500, the Dow Jones Industrial Average, and the NASDAQ, is highly volatile. Besides, it has largely hit the tourism industry, hospitality, aviation, manufacturing, real estate and housing sectors and most industries in many countries are now struggling to survive. These are also relevant to Indonesia in the case of COVID-19. Overall, Indonesia's economy is now one characterised by a decrease in GDP growth rate, increase in unemployment, and the major fluctuation in the exchange rate.

\section{Social cohesion}

Social cohesion indicates human being's interaction with each other in a society that builds a fellow feeling among the members of the society. This foundational principle of society is tremendously hampered due to the pandemic. It is known that one person who is positively infected by the coronavirus and shakes hands with another person, will most likely more than just one other person. Worryingly, it is difficult to say how many people will be infected due to social relationships (hand-shake). As long as a vaccine is not found, there is no alternative for the people of Indonesia to maintain social distance but to simply reduce human contact in order to curtail the spread of the virus. Therefore, the "Lock Down" solution is one of the best solutions for breaking the chain of transmission. As a result, this has meant stopping schools, offices, tourism, industries, and so on. In other words, all public and private sector workplaces are no longer operating or only minimally in Indonesia (Yusnadi 2020). 
Even if it comes to having to cease all activities, regional leaders think about policies that will not affect social cohesion. It is thought that if the economy stops for good, daily necessities will become scarce, prices will soar, and communities will collapse if they cannot get what they need to survive. Indonesian people should have the ability and stoicism to accept these restrictions on their lives. They should think that termination of the virus is the most important thing to achieve and they should be prepared to do whatever needs to be done. As a preventive measure, implementing the strategy of WFH which was introduced by the Indonesian government is one way of maintaining social cohesion to fight COVID-19 transmission (Yusnadi 2020).

\section{Food security}

Food security is realised when all people have access to sufficient, healthy, and nutritious food both physically and economically over a long period of time. Literally, food security is measured from the perspective of an individual's level of access to different dimensions of food intake. The focus is mainly on the nutritional status of individual household members and whether they are receiving enough adequately. Moreover, poverty-stricken people generally experience deficiency of food access and find it difficult to lift their standards above the poverty line (Ferranti, Berry, \& Anderson 2019). During the COVID-19 pandemic, local output-based short food supply chains can serve to ease the influence of external constraints and will help local consumers. To find alternative options, it is important for research activities to establish what the best solutions are in the pandemic-induced crisis, for example technological developments that can enhance short supply chains of food by focusing on local industrial activities. Investment to improve short food supply chains in local areas might enable a community to produce its own food and rely less on global supply chains.

Furthermore, the Coronavirus Resource Center of Harvard Medical School added that the virus should die by cooking food properly and thoroughly. However, foods such as salads and sandwiches might be in places where the virus can develop. Benjamin Chapman, a Professor and Food Safety Specialist at North Carolina State University, said that the coronavirus will not survive on a person's body if that person has a strong immune system and good digestion. He also stated that food is not the main source of transmission of the coronavirus as long as the people themselves do not touch their eyes, nose, or mouth (Rahmawati 2020). Although the virus is very unlikely to spread through food, restaurant and grocery store workers should anticipate the problem with high level hygiene measures. Workers should wash their hands more often, clean the surfaces of cooking areas, cooking utensils, and cook food appropriately at the right temperature (Rahmawati 2020). Food security is a primary concern for governments worldwide, including Indonesia in this time of pandemic and economic crisis. The COVID-19 pandemic has brought about significant disturbances to Indonesian trade, including the security of food and agricultural goods. Production has slowed down, transport and logistics have become an 
obstacle, and avenues of distribution are obstructed as borders have been shut down. Now, countries need to strategize carefully how they can protect their own food supplies. That is definitely true for Indonesia in which, according to the 2019 Global Hunger Index report, many people are struggling with hunger at a significant level. Food shortages or food inflation would affect the population, especially the vulnerable poor, who may spend up to $60 \%$ of their income on food. There is no question that the coronavirus has adversely affected food security, especially in terms of global cooperation and commerce (Amanta 2020).

\section{Supply chain management and industrial production}

Supply chain management is the coordination of the flow of goods and services and involves all processes, transforming raw materials into finished goods. It also includes the streamlining of supply side operations of a company for satisfying customers or clients and achieves a niche in the market. It is a responsibility of the manufacturers to execute supply chains as effectively as possible. Supply chains seek to centrally control the production, transport, and distribution processes whereby a consistent and rational framework is operated and agreed to. Through good supply chain management processes, companies can reduce overhead costs and deliver goods and services more easily and efficiently to customers (Hayes 2019). According to Shokrani et al. (2020), the quarantine effects of the COVID-19 pandemic have severely restricted or simply ended global supplies and output levels. This has coincided with the increasing demands for medical equipment for personal protection, such as face shields. Shortages are now particularly evident in the Western countries that have for the last twenty years been dependent on global supply chains to procure goods and services from low-cost economies. Domestic mass-production facilities are now being reconsidered to satisfy patients' needs in a context in which the virus has culminated in mobilising a complex dispersed workforce. With appropriately minimal equipment and training, medical devices should be easy to manufacture locally.

During the war against the coronavirus, supply chain management is needed which includes storage, transportation, inventory, ordering of goods, and quantity of goods. These now have to be very well integrated, better planned and delivered. Recently, the Government of Indonesia has become concerned with the formulation of a strong public health policy in order to supply the drugs and medical facilities so that the supply chain management process functions properly and patients are cured. The coronavirus has hugely damaged the supply chain in Indonesia, resulting in disruption of medical equipment supply, scarcity of material stock, and overstock due to weak demand for it or the inability to transport it. It is also necessary to assess the realistic requests from customers to anticipate demand shortage, optimise production and distribution capacity, identify the safest logistics distribution, transportation options, and conduct good cash management processes. The supply chain perspective is concerned with ensuring the flow of materials, product movements, starting from upstream (manufacturers or producers) towards downstream (retailers or endconsumers). This includes the flow of goods along with the flow of information and 
funds, as well as the identification of material supply risks caused by the spread of COVID-19 (Kuncoro 2020).

Indonesia imports many goods and services from China because it is one of its largest trading partners. The coronavirus has wrecked trade with China, which has a significant effect on world trade and not just Indonesia. Decline in the demand for raw materials from China such as coal and palm oil will disrupt the export sector in Indonesia, which in turn leads to a substantial decrease in commodity and mining product prices. Thus, the trade sector tax revenues have declined even though trade makes the second largest contribution to tax revenues. Based on data from the Central Statistics Agency (BPS) of Indonesia, oil and gas and non-oil exports have decreased due to China being the largest importer of crude oil. In addition, the spread of the coronavirus resulted in a decrease in the production of China, even though China became the centre of world goods production. If China experiences a decrease in production, the global supply chain will be automatically disrupted and can disrupt the production process as the raw materials are imported from China. Indonesia is largely dependent on raw materials from China, especially plastic raw materials, textile raw materials, electronic parts, computers and furniture.

\section{Discussion}

This study explains the Indonesian government's policies by presenting several nontraditional national security issues during the COVID-19 pandemic. Initially, the law enforcers are forced to compel people to obey the recommended guidelines such maintaining social distance, avoiding mass gatherings, wearing masks, home quarantine, etc. Hence, without cooperation between the community and law enforcement agencies, it will be very difficult to check the spread of the virus. The people must strictly follow the government's updated rules and regulations related to COVID-19 and this situation is applicable to Indonesia. Its government had already declared its policy and implemented measures including holiday extension, hospitalisation, quarantine, travel restrictions, and full city lockdowns to control the impacts of the pandemic (Lin et al. 2020). As well, Indonesian law enforcers are very enthusiastic to enforce social distance and ensure regions are locked down so that the COVID-19 pandemic is controlled. Due to the explosive rate of infection, the law enforcers may suffer from mental health crises at a rate larger than the ordinary people even before dealing with more pandemic challenges, stress, and uncertainty as coincided with the statement of Hartley et al. (2011). Like US police, Indonesian law enforcers are more likely to experience COVID-19 trauma that may severely impact their mental health at a time while they are most needed by the public. Besides, COVID-19 social distancing policies will face drastic challenges as police patrolling won't be workable. As a result, law enforcers' inability will help spread the pandemic causing unimaginable death tolls in the case of Indonesia. To improve officers' mental health, some programs like meditation and yoga (e.g., Tactical Yoga, Yoga for First Responders, and Cop to Yoga) can be offered to positively cope up with pandemic disasters (Stogner et al. 2020). Besides, law enforcers should be encouraged to talk to therapists concerning the mental anxiety of policing. Apart from the individual 
problem, it may mean the need to call in the Indonesian National Army and police force to defend the country against threats and attacks, including the possibility of a CBRNE (Chemical, Biological, Radiological and Nuclear Defence) war (Power 2020).

Kandel et al. (2020) stated that interventions in public health policy will greatly mitigate public health threats, including the outbreak of infectious diseases such as COVID-19. According to Pharm et al. (2020), the necessary travel requirements of business people and tourists must follow healthcare advice, which will help reduce the risk of coronavirus infections. Indonesian authorities are attempting to save people's lives by strengthening the healthcare system and this means restricting all types of tour and travel, which may be the catalyst for eradicating the pandemic in Indonesian territory. Although the Delta variant's spread in this country is minimal, the Alpha variant has spread among the people who disobeyed the travel ban. If it continues, Indonesia could soon be facing an outbreak comparable to India's. More importantly, $40 \%$ of people in Indonesia live on different Islands and the population density in these Islands can put them in very horrible circumstances. Therefore, the recently adopted 20 years' pandemic policy should address all these issues by developing effective health governance in Indonesia.

During the COVID-19 pandemic, economic security is highly constrained in Indonesia. Mamun and Ullah (2020) stated that the pandemic is causing huge revenue losses which are similar to elsewhere in the world. This country's economic security is now vulnerable, and if consumers are able to get their daily essentials flexibly, this may encourage them to purchase more. This may even stimulate investment and lead to a multiplier effect for the economy. The current economic disaster has dramatically increased the unemployment rate and especially in the manufacturing sector (Nicola et al. 2020). In this case, increase in locality-based production in agriculture, small and medium-sized enterprises might be the key to reach a particular level of economic growth for the Indonesian economy. Some stimulus packages like loans with lower interest rates for local producers may encourage them to concentrate on their business practices. The tourism industry may recover through the proper management of tourism destinations in Indonesia as long as the COVID-19 pandemic can be controlled. If the economic sectors are not taken care of properly, Indonesia might witness some negative consequences. As per Oxford Economics, the Indonesian economy may experience a massive deficit in consumer and infrastructure expenditure (Agarwal et al. 2021). Besides, the Indonesian government's focus on resilient healthcare systems, faster adoption of digital technologies, environmental safety, supply-chain reliability, and a larger enthusiasm to sacrifice some privacy for better health, safety, and comfort guarantees might be hampered. The mega-investment in the digitization of the agricultural sector will be largely hindered due to the lack of capital scarcity in Indonesia. Moreover, $90 \%$ of workers engaged in the country's industrial sector might face no pay following the continuance of the pandemic.

Social cohesion is totally affected by the spread of the COVID-19 pandemic. Studies reveal that the indigenous communities in Indonesia are more likely to be vulnerable. When people are returning to their communities in various rural areas, locals are not accepting them eagerly due to the suspicion of the virus 
infection existing in returnees' bodies. People who are moving or migrating suffer from language barriers, poor water access, limited internet access and even lack protective materials such as masks, sanitisers, face shields (Martínez et al. 2020). Although people are experiencing difficulties in their movements, they have to consider the interests of the wider society. One of the best alternatives to cope with the COVID-19 pandemic is to obey the social distancing policy of the government. Control of travel and mobility, effective case identification and exclusion, quarantining and body-checking, and overall community-wide surveillance can also be effective policies to ensure social integration (Yezli and Khan, 2020) in each and every area of the country. People's continuous separation from their family and neighbours can put them in a state of isolation, increasing mental depression. Loneliness and captive life are detrimental to the fellow feelings that may even dismantle the bond and cohesion in Indonesian society. Moreover, banning all types of social rituals and programs lead to losing the conventional idiom 'one's for all and vice versa.'

Food security is not free from the disastrous effects of COVID-19. According to Cappelli and Cini (2020), it is necessary to conduct a critical analysis to improve the short supply chain of food in each region in order to ensure people have access to healthy foods regularly. Handu et al. (2020) pointed out that COVID-19 has increased the potential malnutrition of people. Attention to nutritional care is a critical aspect of public health in Indonesia during the COVID-19 pandemic. The country is very much aware about the production and distribution of food supplies. As there is a weak evidence of virus infection via food consumption, the country has continued to provide safety materials for those people who work in food supply and distribution jobs. Introducing a short food supply chain strategy would not be a very difficult task for the Indonesian food producers and government. Lack of food supply will be a substantial threat to human health. In Indonesia, more than $40 \%$ of people live in various Islands spread all over the country. These densely populated Islands might witness inadequate food supply, causing people's starvation. Besides, people engaged in food supply-related activities might be in problem due to a colossal halt in operating food industries. Overall, food processing, storing and supplies will tremendously be obstructed in this economy. A major trend might appear that smallholders will take up rural survival way and turn back to agriculture. More importantly, Indonesian households can shift to higher consumption of carbohydrates which will have a harmful impact on nutrition.

The supply chain management relating to industrial goods is a complex issue for the Indonesian government. Shokrani et al. (2020) stated that policies of different countries to stop the spread of coronavirus have urgently reshaped the complex supply chain of both goods and manufacturing materials. They explored the viability of new production methods and unused supply chains. According to Govindan et al. (2020), a practical decision will be required in the supply chain process due to increasing and long-term disruptions in supply chains across the world. Based on the Institute for Supply Chain Management, in its survey conducted in March 2020, it has been reported that nearly $75 \%$ of companies globally have been facing supply chain disruptions due to COVID-19 and especially 
transportation restrictions. Likewise, the Indonesia's experience of COVID-19 is very critical in terms of trade restrictions with China. The vulnerability of Indonesia concerning the supply chain of industrial primary goods such as textile raw materials, plastic raw materials, computers and furniture, and the electronic parts are immense as the country imports these raw materials from China. Some cautious attempts to restart business with China will be made because economic conditions for people in Indonesia are now reaching the desperation stage. Due to the continuance of the pandemic, the Indonesian case will be critical as the non-movement of goods and materials both domestically and internationally will lead to irreparable potential losses in industry and healthcare supply chains. This country is more likely to face supply chain disruptions or unexpected delays in receiving orders. Perhaps, such problems will be compounded by supply chain information blackout from China (Sengupta 2020).

\section{Conclusion and policy recommendations}

This study examines the impacts of the COVID-19 pandemic on the different nontraditional national security issues in Indonesia. The results find that COVID-19 has largely impacted the law enforcement body as their duties and workload have increased, causing their mental health problem. From the legal aspect, Indonesian government has ratified the Government Regulations and Presidential Decrees concerned with coronavirus-related issues. Proper motivation and financial incentives may reduce the anxiety of the law enforcers. Besides, Yoga, meditation and mental therapy may be applied in the case of law enforcers' mental healthrelated problem, making them workable in duty. Moreover, government's prudent and sustainable policy measures are dire need to implement social distancing and restricted movement/travel approaches. Pandemic has devastatingly affected health security in Indonesia as revealed through the existence of Public Health Emergency status in all regions. It is concerned with how to define extraordinary public health events marked by the spread of infectious diseases that pose serious health hazards and have the potential to spread throughout regions or to other countries. So, government should continue case identification and treatment from village level community clinic to national level hospitals to tackle the abnormal spread of pandemic for the sake of public health.

COVID-19 has greatly diminished the economy which recorded only $2.3 \%$ growth rate and it may fall down to $0.4 \%$ if the pandemic continues. The increase in unemployment in Indonesia is also evident and furthermore COVID-19 has threatened social cohesion in Indonesia, resulted in the government forced to adopt a 'lock down' policy to discourage public movement and gatherings, going to schools, colleges, universities and other workplaces. This drastic change in public policy intends to break the chain of the spread of the COVID-19 pandemic in and beyond Indonesia. COVID-19 has impacted on the daily consumption level of people in Indonesia. This is expressed by the government compelling food workers to use protected materials and following necessary hygiene regimes in order to control the pandemic, although virus transmission via food intake is not 
proven. However, the virus itself spreads through droplets of bodily fluids from someone infected with it and is generally transmitted to others through touching, coughing or sneezing.

Lastly, COVID-19 impacts adversely on Indonesia's supply chain management. The country has been experiencing mismanagement of the supply chain and led to significant scarcity of virus protective material supplies and stock due to huge demand. Therefore, it is necessary to assess the realistic situation to cope with demand, optimising production and distribution capacity, safe logistics distribution, and transportation options. Moreover, good cash management must be maintained to avoid liquidity and financial distress issues.

As the policy recommendations of this study are to be highly concerned with pandemic control, all these security issues like law enforcement, health, economy, supply chain and social cohesion should be dealt with properly by adopting some common short and long-term policies. In the short-term period, the country could accelerate the distribution of social welfare schemes and simultaneously complement the recipient data by combining government and community data. Secondly, the government needs to integrate the unemployment data and what is required in terms of welfare assistance received by poor people and now those who have just joined the ranks of the unemployed. Thirdly, the government can take immediate action and policy measures to expand the Employment Card assistance scheme by prioritising the underprivileged and/or unemployed people, especially those who have been affected by COVID-19. Here, the main aim of the government should be to meet the basic needs of all people who have lost their jobs. Next, the government should encourage all businesses by providing strategies for them to retain as much of their workforce as possible rather than engage in mass layoffs. Social assistance must be made available to all communities in every part of Indonesia.

Several recommended policies can be enacted by local governments throughout Indonesia. Firstly, they can strengthen strict community mobilisation to combat the virus's transmission at the community level. Secondly, they can collect data on virus infection rates and ensure the availability of regional budgets to treat patients and protect Indonesian healthcare workers. There needs to be good coordination between the Ministry of Health and Department of Health and local governments and based on updated information, these wings shall provide the necessary personal protective equipment (PPE) to the people. Thirdly, local governments can reinforce the readiness of health facilities by preparing COVID-19 referral hospitals in each region and increase the capacity of community health centers in terms of knowledge, prevention, detection, handling and monitoring of mild cases of COVID-19. Next, local governments should encourage all communities down to the village level by establishing "COVID-19 alert villages". More public participation has been one of the World Health Organization's key strategies for strengthening primary healthcare services. Local governments should have the flexibility to collaborate with the private sector, philanthropist bodies, universities, and other non-governmental organisations to devise COVID-19 prevention strategies in all regions of Indonesia. Moreover, Indonesian governmental is policy is intended to maintain the domestic economic growth rate during 
the COVID-19 outbreak. Bank Indonesia should keep a close watch on global and domestic economic developments, in order to keep inflation and external circumstances under control. Finally, national security issues are very critical for the future development of Indonesia. Only the right policies chosen by the government can give the country the desired growth trajectory if the pandemic is stopped effectively.

The study has some limitations. Firstly, not all the national security issues have been explored here. Shortage of literature means that there is not enough recent data to be accessed. The impacts of COVID-19 on other relevant issues like financial markets (Alam et al. 2021), technology use, energy (Aktar et al. 2021), sport (Alam and Abdurraheem 2021), and education are obvious, but not included in this study. Further research is essential this will mean incorporating more literature, undertaking a longer time span and inferential statistics in this field. Despite this, our findings have some application not only to Indonesia but other developing economies. The world's major economies can consider their strategies for supporting businesses based on the outcomes obtained from this analysis of Indonesia.

Author contributions MMA Conceptualization, Project administration, Supervision, Writing-review and editing. AMF Methodology, Formal analysis, Writing-original draft. MMI Formal analysis, Writingreview and editing. JS Revising; formatting and improve.

Funding The authors received no funding for this work.

Data availability The data are collected from publicly available sources.

Code availability Not applicable.

\section{Declarations}

Conflict of interest There is no conflict of interest related to this work.

\section{References}

Agarwal, R., A. Santoso, K.T. Tan, and P. Wibowo. 2021, May 3. Ten Ideas to Unlock Indonesia's Growth After COVID-19. McKinsey \& Company. https://www.mckinsey.com/featured-insights/asia-pacific/ ten-ideas-to-unlock-indonesias-growth-after-covid-19 Accessed on 15 Sept 2021.

Agustino, G.L. 2020, April 24. Prohibition Officially Applies, the Flow of Boat Passengers in the Port of Tanjung Priok Stops. Accessed from TribunJakarta.com: https://jakarta.tribunnews.com/2020/04/ 24/larangan-mudik-resmi-berlaku-arus-penumpang-kapal-di-pelabuhan-tanjung-priok-berhenti.

Aktar, M.A., M.M. Alam, and A.Q. Al-Amin. 2021. Global Economic Crisis, Energy Use, $\mathrm{CO}_{2}$ Emissions and Policy Roadmap amid COVID-19. Sustainable Production and Consumption 26: 770781. https://doi.org/10.1016/j.spc.2020.12.029.

Alam, M.M., and I.I. Abdurraheem. 2021. COVID-19 and the Financial Crisis in the Sports Sector around the World. Sport in Society. https://doi.org/10.1080/17430437.2021.1979964.

Alam, M.M., H. Wei, and A.N.M. Wahid. 2021. COVID-19 Outbreak and Sectoral Performance of the Australian Stock Market: An Event Study Analysis. Australian Economic Papers 60 (3): 482-495. https://doi.org/10.1111/1467-8454.12215. 
Aldis, W. 2008. Health Security as a Public Health Concept: A Critical Analysis. Journal of Health Policy and Systems Research 23 (6): 369-375.

Amanta, F.A. 2020, April 4. Preventing Global Food Crisis Caused by COVID-19. Accessed from_ TheJakartaPost:_https://www.thejakartapost.com/academia/2020/04/04/preventing-global-food-crisis-caused-by-covid-19.html.

Arnani, M. 2020, April 4. Corona Virus Update in Indonesia: Details of COVID-19 Cases in 32 Provinces. Accessed from KOMPAS: https://www.kompas.com/tren/read/2020/04/04/174720065/2092orang-terinfeksi-corona-ini-rincian-kasus-di-32-provinsi-di-indonesia.

Basrowi. 2020, March 26. Supply Chain Management as the Solution to Fight Corona Virus. Accessed from SUARA: https://www.suara.com/yoursay/2020/03/26/132350/supply-chain-managementsebagai-solusi-perangi-virus-corona.

Bherwani, H., S. Anjum, S. Kumar, S. Gautam, A. Gupta, H. Kumbhare, A. Anshul, and R. Kumar. 2020. Understanding COVID-19 Transmission Through Bayesian Probabilistic Modeling and GIS-Based Voronoi Approach: A Policy Perspective. Environment, Development and Sustainability. https://doi. org/10.1007/s10668-020-00849-0.

Cappelli, A., and E. Cini. 2020. Will the COVID-19 Pandemic Make Us Reconsider the Relevance of Short Food Supply Chains and Local Productions? Trends in Food Science and Technology 99: $566-567$.

Changotra, R., H. Rajput, P. Rajput, S. Gautam, and A.S. Arora. 2020. Largest Democracy in the World Crippled by COVID-19: Current Perspective and Experience from India. Environment, Development and Sustainability. https://doi.org/10.1007/s10668-020-00963-z.

CSIS. 2021. Southeast Asia COVID-19 Tracker. Center for Strategic and International Studies (CSIS). https:/www.csis.org/programs/southeast-asia-program/projects/southeast-asia-covid-19-tracker.

Ferranti, P., E.M. Berry, and J.R. Anderson. 2019. The Concept of Food Security. In Encyclopedia of Food Security and Sustainability, Vol. 2, 1-7. Amsterdam: Elsevier.

Gautam, S. 2020. COVID-19: Air Pollution Remains Low as People Stay at Home. Air Quality, Atmosphere and Health 13 (7): 853-857. https://doi.org/10.1007/s11869-020-00842-6.

Govindan, K., H. Mina, and B. Alavi. 2020. A Decision Support System for Demand Management in Healthcare Supply Chains Considering the Epidemic Outbreaks: A Case Study of Coronavirus Disease 2019 (COVID-19). Transportation Research Part E: Logistics and Transportation Review 138: 101967.

Grizold, A. 1994. The Concept of National Security in the Contemporary World. International Journal of World Peace 11 (3): 37-53.

Hameiri, S., and L. Jones. 2013. The Politics and Governance of Non-traditional Security. International Studies Quarterly 57 (3): 462-473.

Handu, D., L. Moloney, M. Rozga, and F. Cheng. 2020. Malnutrition Care During the COVID-19 Pandemic: Considerations for Registered Dietitian Nutritionists Evidence Analysis Center. Journal of the Academy of Nutrition and Dietetics 121 (5): 979-987.

Hartley, T.A., C.M. Burchfiel, D. Fekedulegn, M.E. Andrew, and J.M. Violanti. 2011. Health Disparities in Police Officers: Comparisons to the US General Population. International Journal of Emergency Mental Health 13 (4): 211.

Hayes, A. 2019, August 11. Supply Chain Management (SCM). Accessed from Investopedia: https:// www.investopedia.com/terms/s/scm.asp.

Hidayati, K.F. 2020, April 2. The Coronavirus' Impacts on the Indonesian Economy. Accessed from Glints: https://glints.com/id/lowongan/dampak-virus-corona-bagi-perekonomian/\#.Xo27D HJS82w.

ILO. 2012. Definitions: What We Mean When We Say "economic security". ILO Socio-economic Security Programme. https://www.ilo.org/public/english/protection/ses/download/docs/defin ition.pdf.

Kandel, N., S. Chungong, A. Omaar, and J. Xing. 2020. Health Security Capacities in the Context of COVID-19 Outbreak: An Analysis of International Health Regulations Annual Report Data from 182 Countries. Lancet 395 (10229): 1047-1053.

Ketchell, M. 2021. Setahun pandemi di Indonesia: 3 kelemahan terbesar kebijakan pengendalian COVID-19 sehingga gagal total. The Conversation. https://theconversation.com/setahun-pandemidi-indonesia-3-kelemahan-terbesar-kebijakan-pengendalian-covid-19-sehingga-gagal-total-155129.

Kumar, D., R. Malviya, and P.K. Sharma. 2020. Coronavirus: A Review of COVID-19. EJMO 4 (1): $8-25$. 
Kuncoro, H. 2020, March 17. Impacts of the Coronavirus Outbreak: Mitigation Plan in Logistics, Factories and Operations Areas. Accessed from SupplyChainIndonesia: https://supplychainindonesia. com/dampak-wabah-virus-corona-mitigation-plan-di-area-logistik-pabrik-dan-operasional/.

Lin, Q., S. Zhao, D. Gao, Y. Lou, and S. Yang. 2020. A Conceptual Model for the Coronavirus Disease 2019 (COVID-19) Outbreak in Wuhan, China with Individual Reaction and Governmental Action. International Journal of Infectious Diseases 93: 211-216.

Mamun, M.A., and I. Ullah. 2020. COVID-19 Suicides in Pakistan, Dying Off Not COVID-19 Fear But Poverty? The Forthcoming Economic Challenges for a Developing Country. Brain, Behavior, and Immunity 87: 163-166.

Martínez, L.D., L. de la Vega, A. Ramírez, M. Aguilar, and R. Ramírez. 2020. Critical Review of Social, Environmental and Health Risk Factors in the Mexican Indigenous Population and Their Capacity to Respond to the COVID-19. Science of the Total Environment 733: 139357.

Nainggolan, P.P. 2020, March 18. Corona Outbreak and National Security. Accessed from TEMPO: https://kolom.tempo.co/read/1320840/wabah-corona-dan-keamanan-nasional/full\&view=ok.

Nicola, M., Z. Alsafi, C. Sohrabi, and A. Kerwan. 2020. The Socio-economic Implications of the Coronavirus and COVID-19 Pandemic: A Review. International Journal of Surgery 78: 185-193.

Novianto, R.D. 2020, March 30. Jokowi Ready to Enforce Civil Emergency for Corona Weir: Detailed of Regulations. Accessed from SINDONEWS: https://nasional.sindonews.com/read/1572919/14/ jokowi-siap-berlakukan-darurat-sipil-bendung-corona-begini-aturannya-1585566589.

Pharm, T.A., K. Chin, D. Liew, and R. Asenso. 2020. Rethinking Pandemic Preparation: Global Health Security Index (GHSI) is Predictive of COVID-19 Burden, But in the Opposite Direction. Journal of Infection 81 (2): 318-356.

Power, S. 2020, April 14. How the COVID-19 Era Will Change National Security Forever. Accessed from TIME: https://time.com/5820625/national-security-coronavirus-samantha-power/.

Pristiwasa, I.W. 2020, April 9. The Impact of COVID-19 on the Tourism Sector. Accessed from MinangkabauNews: https://minangkabaunews.com/artikel-25278-dampak-covid19-terhadap-sektor-pariw isata.html.

Rahmawati, Y. 2020, March 30. Could Coronavirus Spread Through Packaged Foods? Accessed from SUARA: https://www.suara.com/health/2020/03/30/161558/mungkinkah-virus-corona-covid-19menyebar-lewat-makanan-kemasan?page $=$ all.

Sadikin, R.A. 2020, April 1. What is the Public Health Emergency Status Amid Corona Pandemic? Accessed from SUARA: https://www.suara.com/news/2020/04/01/111456/apa-itu-status-kedaruratan-kesehatan-masyarakat-di-tengah-pandemi-corona.

Sengupta, A. 2020, April 14. Impact of COVID-19 on Global Supply Chains and Opportunities in the Post-COVID World. Accessed from EntrepreneurIndia: https://www.entrepreneur.com/article/ 349229.

Shokrani, A., E. Loukaides, E. Elias, and A. Lunt. 2020. Exploration of Alternative Supply Chains and Distributed Manufacturing in Response to COVID-19: A Case Study of Medical Face Shields. Materials and Design 192: 108749.

Stogner, J., B.L. Miller, and K. McLean. 2020. Police Stress, Mental Health, and Resiliency during the COVID-19 Pandemic. American Journal of Criminal Justice 45 (4): 718-730. https://doi.org/10. 1007/s12103-020-09548-y.

Wahyono, W. 2017. National Security in a New Perspective. Journal of National Defense 5 (1): 19-34.

Wingard, M. 2020, March 30. COVID-19: Looming Crisis in Developing Countries Threatens to Devastate Economies and Ramp Up Inequality. Accessed from United Nations Development Programme (UNDP): https://www.undp.org/content/undp/en/home/news-centre/news/2020/COVID19_Crisis_ in_developing_countries_threatens_devastate_economies.html.

Worldometer. 2020, June 28. Coronavirus Cases: Indonesia. https://www.worldometers.info/coronavirus/ country/indonesia/.

Worldometer. 2021, July 14. Coronavirus Cases: Indonesia. https://www.worldometers.info/coronavirus/ country/indonesia/.

Yezli, S., and A. Khan. 2020. COVID-19 Social Distancing in the Kingdom of Saudi Arabia: Bold Measures in the Face of Political, Economic, Social, and Religious Challenges. Travel Medicine and Infectious Disease 37: 101692.

Yusnadi, A. 2020, March 16. Corona and Social Impacts. Accessed from AnteroAceh: https://anteroaceh. com/news/corona-dan-dampak-sosial/index.html. 
Publisher's Note Springer Nature remains neutral with regard to jurisdictional claims in published maps and institutional affiliations.

\section{Authors and Affiliations}

Md. Mahmudul Alam ${ }^{1}$ (D) Agung Masyad Fawzi ${ }^{1} \cdot$ Md. Monirul Islam² ${ }^{2}$ Jamaliah Said ${ }^{3}$

Agung Masyad Fawzi

mf.agung96@gmail.com

Md. Monirul Islam

monirdu1981@gmail.com

Jamaliah Said

jamaliah533@uitm.edu.my

1 School of Economics, Finance and Banking, Universiti Utara Malaysia, Sintok, Malaysia

2 Department of Governance and Public Policy, Bangladesh Institute of Governance and Management (BIGM), University of Dhaka, Dhaka, Bangladesh

3 Accounting Research Institute, Universiti Teknologi MARA, Shah Alam, Malaysia 